DOI: https://doi.org/10.24297/ijrem.v10i0.8450

\title{
Agrochemical Indicatıons Of The Deposits Of Azerbaijan And Effect Of Erosıon Process On Plant Productivity
}

\author{
Dr. Prof. Z.H. Aliyev
}

Institute of Soil Science and Agrochemistry of ANAS, Baku-2019

Volqa_5@mail.ru

\section{Annotation:}

Taking all these into account, it is important to increase the fertility of the soil from the erosion process in Ismayilli and to prevent the washing of fodder crops from perennial herbs. The cultivation of these plants in the mountainous regions protects the slopes from the terrible erosion process and provides the animals with a strong fodder. It is proved by the results of the research that restoration of fertility and ecological balance of erosion lands and the implementation of soil-agro-technical measures to increase productivity are of great importance. Due to the application of these measures, I, as a result of improving the water and physical properties of the affected land, prevent surface water flows. In addition, the results of the study have been proven by the fact that, for certain reason, erosion and erosion hazards are most likely to be taken over by the sowing of perennial herbs. Thus, perennial herbs, in particular, accumulate the nitrogen atmosphere of the legumes, enriches the soil with organic matter, accelerates the formation of water-resistant granular - topical structure and improves its water-physical properties, which in turn facilitates the rapid digestion of foodstuffs.

Keywords: Ecosystem, Erosion, Slopes, Cross Country, Soil Characteristics, Mountain Gray-Brown Soils, Degraded, Etc.

\section{Introduction}

Preservation and effective use of natural resources and the environment in the Republic of Azerbaijan is one of the important components of the State's socio-economic policy. Multiple national programs adopted in this area cover a fairly wide range of land covering the urgent solution of disputes. It should be noted that for the purpose of preserving the rich flora and fauna of the country, the establishment and expansion of national parks and forests, cleaning of contaminated soils and water basins, modernization of hydrometeorological service, etc. is being used to address important environmental problems.

Elimination of ecological environment in the territory of the Republic, reduction of forests, meadows, useful land of agricultural destination, elimination in some places, violation of biological diversity of some plants and animals, etc. increasing the relevance and relevance of the ecosystem assessment as a whole.

The soil cover has been formed as an important component of the biosphere and as a result of the influence of abiotic, biotic, and anthropogenic factors forming the earth as a free nature. Soil ecosystems and their erosion are the main criteria that constitute the basis for biological activity, plant productivity cultivated on the soil, and the environmental assessment of the product obtained by evaluating soil and its forming factors in such interactions. Degradation of soil and its ecological assessment, as well as one of the new areas of soil science, explain the ecological nature of the processes occurring in the soil and its causes, its dynamics, and legitimacy on scientific grounds. In this regard, the land affected by the natural and anthropogenic impacts, as well as in all-natural areas of the Republic, covers a wide range of areas in the Shamakhi region, which covers the southeastern slopes of the Greater Caucasus. The total area of the district is 215875.0 hectares, of which 127.5 thousand hectares $(58.7 \%)$ are 55.8 thousand hectares (25.7\%) of various degraded soils, 28.3 min hectares (13.0\%) and 43.4 thousand hectares (20.0\%) were subject to severe erosion. 
The relief of the Shamakhi region is very complicated, and erosion is widespread in the region as a result of anthropogenic pressure.

Strongly affecting the occurrence of erosion, the sharp change in relief, the form of slopes, the amount of falling rainfall, the intensity and duration, the economic activity of people, and other factors.

Because of the ignorance of the soil on the slopes used under the plow, these areas have been completely deteriorated. The Shamakhi region's agricultural zone is mainly composed of low, medium, mountainous, and mountainous plains. The erosion process in the mountain farming zone has intensified and has spoiled large areas.

The use of sown areas in the slopes for a long time under the same plant, especially under grain crops, the application of herbaceous crop rotations, and the lack of organic fertilizers have further erode. It can be said that species and species of erosion are found in Shamakhi region.

In the Shamakhi region, mountain gray-brown soils cover a wide area and are mainly used under grain crops. Mountain gray-brown soils are at the height of 500-600 meters above sea level. In soil exposed to intensive anthropogenic tension, erosion has aggravated the agrochemical composition of the soils and agrophysiological properties.

The gray-brown soils of the mountain form a transition between the forest-steppe and plain zones and differ significantly from those spread out in those zones.

A number of scholars have provided extensive information on the occurrence, genetic features, distribution and use of gray-brown soils in Azerbaijan [1,2,3,4].

\section{The object and method of research}

The research was set up in the village of Melham, Shamakhi region. The study was conducted on this scheme.

1st area (Supervision);

2. The poem,

3. clover.

The influence of perennial herbs (kasha, yonca) on the dynamics of volatile food in mountainous brown soils eroded in the Ismayilli region, south-east of the Greater Caucasus, has been studied. The research was widely used in the field of soil sciences K.A. Based on Alekberov's methodology [2]. It should be noted that clean and mixed sprouting of perennial herbs (khash and clover) in mountainous regions of our Republic, including the improvement of eroded soils in the southeastern slopes of the Greater Caucasus (Shamakhi region).

Perennial herbs have accumulated a large amount of root mass on eroded soil and improve their structure and increase their fertility. For certain purposes, the research object was investigated in the Chemical Analyzes Laboratory, using samples taken on the soil and taking soil samples.

Humus;

Total nitrogen - IV Thurin;

Mutagenic phosphorus -B.P. Method of math;

The absorbed ammonia-R. R. Konev; 
Ammonia-Nesler reagent soluble in water;

Nitrate nitrogen - Granand lavage;

Acquired Causes (Ca, Md) -D.V. Ivanov method.

\section{Material Analysis and Discussion}

From our research, it is clear that the brown brown, brown-brown soils used intensively in agriculture in the middle and low mountainous areas of the region are more eroded. The study was carried out in gray-brown soils, and the effect of erosion on nutrients was investigated. The damage caused by erosion to soil fertility can be traced to the morphological features of the soil cuts and the results of the analyzes carried out in the natural field.

\section{Research progress:}

Some soil-agrochemical characteristics of these soils have been studied to determine the effects of the erosion process on the fertility of the studied soils. The analysis of the research materials suggests that the erosion process has resulted in anthropogenic factors and as a result of hydrotermic conditions, changes in nutrients in these soils, and deterioration of some signs.

The mechanical composition of mountain gray-brown soils is heavy-gill and clay, profile carbonate. The majority of the clay and white clays on the lower layers of the middle layer of the soil profile and moderately eroded in the erosion are related to the illudial layer of these soils. [3,4]

It has been established that the amount of physical clay on the upper layers of the gray-brown soils $(0-13,13-$ $31 \mathrm{~cm}$ ) not exposed to erosion is 54,48-59,60\%, humus 3,13-3,34\%, total nitrogen $0,13-0,16 \%$, absorbed ammonia 64,35-76,70 mg / kg, water-soluble ammonia 15,21-17,70 mg / kg, nitrates 4,39-5,90 mg / kg total phosphorus 0,20 ( $\mathrm{Ca}+\mathrm{Md}) 34, \%$ of total potassium 3,07-3,11\%, exchanged potassium 344,19-359,49 mg / kg, carbonate 7,27-10,39\% Varies between 41-39,08 mq.ekv (100 g of land).

Humus is $1.46-1.87 \%$, total nitrogen $0.10-0.07 \%$, absorbed ammonia 33.90-57.00 mg / kg, water-soluble soil, in moderately degraded soil compared to non-eroded gray-brown soils ammonia 9,32 -11,40 mg/kg, nitrates 2,82 $-3,42 \mathrm{mg} / \mathrm{kg}$, general phosphorus 0,11 -0,14\%, total potassium 2,16 -2,90\% (Table 1) .

Since the erosion process has absorbed the organic layer rich in organic matter, its physical properties have not been significantly degraded in erosion type $1.23-1.20 \mathrm{~g} / \mathrm{cm}$, special 2.69-2.67 g/ cm3, pores 54.28 -55,06\%, while moderate erosion was reduced by 1.29 to $1.24 \mathrm{~g} / \mathrm{cm}$, with a specific weight of $2.72-2.68 \mathrm{~g} / \mathrm{cm}^{3}$ and pallor 52.57 to $-53.74 \%$ (Table 2 ).

It was determined that humus 116,91 t/hex,\%, total nitrogen 7,12 t/hex, absorbed ammonia 398,77 kg/hek, water-soluble ammonia $92-50 \mathrm{~cm}$ layer of gray-brown soils not eroded, $03 \mathrm{~kg} /$ hectare, nitrates $29.17 \mathrm{~kg} / \mathrm{hectare}$, total nitrogen forms $519.97 \mathrm{~kg} / \mathrm{hectare,total}$ phosphorus $10.95 \mathrm{t} / \mathrm{hex}$, mesophore phosphorus $114.11 \mathrm{~kg} / \mathrm{hek}$, total potassium 187.03 t/hectare, potassium exchange was $2106.70 \mathrm{~kg} / \mathrm{hectare}$.

Humus reserves in the $0-50 \mathrm{~cm}$ layer of moderate erosion compared to the erosion type of these lands are 71,88 hectares, total nitrogen 3,47 t/hectare, absorbed ammonia 175,68 kg/hex, water soluble ammonia 33,02 $\mathrm{kg} /$ hectare, total potassium - $38.53 \mathrm{t} /$ hectare, potassium potassium - $943.47 \mathrm{~kg} / \mathrm{hectare}$.

The average humus content of these soils is $1.46-1.87 \%$, humus reserves of $0-50 \mathrm{~cm}, 71.88 \mathrm{t} /$ hectare, the total nitrogen content of $0.10-0.07 \%$, reserve $3,47 \mathrm{t} /$ hectare less. 
Table 1

Agrochemical indicators of mountain gray-brown soils (in absolute dry land)

\begin{tabular}{|c|c|c|c|c|c|c|c|c|c|c|c|c|}
\hline \multirow{2}{*}{$\begin{array}{l}\text { Cut off } \\
\text { Numbe } \\
r\end{array}$} & \multirow{2}{*}{$\begin{array}{l}\text { Ge } \\
\text { net } \\
\text { ic } \\
\text { lay } \\
\text { ers }\end{array}$} & \multirow{2}{*}{$\begin{array}{l}\text { De } \\
\text { pth } \\
\text { in } \\
\text { sm }\end{array}$} & \multirow{2}{*}{$\begin{array}{l}\text { Hu } \\
\text { mus } \\
\text { in\% }\end{array}$} & \multirow{2}{*}{$\begin{array}{l}\text { Tot } \\
\text { al } \\
\text { nitr } \\
\text { oge } \\
\text { n, } \\
\text { in\% }\end{array}$} & \multicolumn{3}{|c|}{$\begin{array}{l}\text { Nitrogen forms mg } \\
/ \mathrm{kg}\end{array}$} & \multicolumn{2}{|c|}{$\begin{array}{l}\text { Phosphoru } \\
\text { s }\end{array}$} & \multicolumn{2}{|c|}{ Potassium } & \multirow{2}{*}{$\begin{array}{l}\mathrm{CaCO} \mathrm{CO}_{3} \\
\text { by } \mathrm{CO}_{2} \%-- \\
\text { with }\end{array}$} \\
\hline & & & & & $\begin{array}{l}\text { It's } \\
\text { abso } \\
\text { rbed } \\
\text { amm } \\
\text { onia }\end{array}$ & $\begin{array}{l}\text { Solu } \\
\text { ble } \\
\text { in } \\
\text { wate } \\
r \\
\text { amm } \\
\text { onia }\end{array}$ & $\begin{array}{l}\text { Nitr } \\
\text { ates }\end{array}$ & $\begin{array}{l}\text { om } \\
\text { mo } \\
\mathbf{n} \\
\mathrm{P}_{2} \mathrm{O} \\
5 \\
\mathrm{mq} / \\
\mathbf{k q}\end{array}$ & $\begin{array}{l}\text { Flex } \\
\text { ible } \\
\mathrm{P}_{2} \mathrm{O} \\
5 \\
\mathrm{mq} / \\
\mathrm{kq}\end{array}$ & $\begin{array}{l}\text { com } \\
\text { mo } \\
\text { n\%- } \\
\text { wit } \\
\text { h }\end{array}$ & $\begin{array}{l}\text { Excha } \\
\text { nged } \\
\text { mg / } \\
\text { kg }\end{array}$ & \\
\hline \multicolumn{13}{|c|}{ No erosion } \\
\hline \multirow{5}{*}{1} & $A_{1}$ & $0-13$ & 3,34 & $\begin{array}{l}0,16 \\
0\end{array}$ & 76,70 & 17,70 & 5,90 & 0,23 & $\begin{array}{l}22,5 \\
1\end{array}$ & 3,11 & $\begin{array}{l}359,4 \\
9\end{array}$ & 7,27 \\
\hline & $A_{2}$ & $\begin{array}{l}13- \\
31\end{array}$ & 3,13 & $\begin{array}{l}0,13 \\
1\end{array}$ & 64,35 & 15,21 & 4,39 & 0,20 & $\begin{array}{l}20,4 \\
4\end{array}$ & 3,07 & $\begin{array}{l}344,1 \\
9\end{array}$ & 10,39 \\
\hline & $B$ & $\begin{array}{l}31- \\
50\end{array}$ & 1,13 & $\begin{array}{l}0,07 \\
3\end{array}$ & 58,00 & 13,05 & 4,35 & 0,12 & $\begin{array}{l}14,3 \\
2\end{array}$ & 2,92 & $\begin{array}{l}217,9 \\
8\end{array}$ & 18,55 \\
\hline & $B C$ & $\begin{array}{l}50- \\
72\end{array}$ & 0,85 & $\begin{array}{l}0,04 \\
4\end{array}$ & 46,40 & 11,60 & 2,90 & 0,08 & $\begin{array}{l}10,3 \\
7\end{array}$ & 2,97 & $\begin{array}{l}202,2 \\
1\end{array}$ & 19,85 \\
\hline & C & $\begin{array}{l}72- \\
95\end{array}$ & 0,59 & $\begin{array}{l}0,02 \\
9\end{array}$ & 34,50 & 10,06 & 1,44 & 0,05 & 6,25 & 2,95 & $\begin{array}{l}114,6 \\
2\end{array}$ & 14,71 \\
\hline \multicolumn{13}{|c|}{ Medium degree of erosion } \\
\hline \multirow[t]{3}{*}{2} & $A_{2}$ & $0-10$ & 1,87 & $\begin{array}{l}0,10 \\
1\end{array}$ & 57,00 & 11,40 & 3,42 & 0,14 & $\begin{array}{l}13,2 \\
3\end{array}$ & 2,90 & $\begin{array}{l}253,3 \\
3\end{array}$ & 13,35 \\
\hline & 5 & $\begin{array}{l}10- \\
29\end{array}$ & 1,46 & $\begin{array}{l}0,07 \\
3\end{array}$ & 33,90 & 9,32 & 2,82 & 0,11 & $\begin{array}{l}12,4 \\
9\end{array}$ & 2,16 & $\begin{array}{l}176,3 \\
7\end{array}$ & 19,72 \\
\hline & $B C$ & $\begin{array}{l}29- \\
55\end{array}$ & 0,75 & $\begin{array}{l}0,02 \\
9\end{array}$ & 27,75 & 8,32 & 1,39 & 0,05 & 4,16 & 2,50 & 72,87 & 20,48 \\
\hline
\end{tabular}


Table 2

Some physical properties of mountain gray-brown soils

\begin{tabular}{|c|c|c|c|c|c|c|}
\hline $\begin{array}{l}\text { Number } \\
\text { of sliced } \\
\text { cuts }\end{array}$ & $\begin{array}{l}\text { Degree of } \\
\text { erosion }\end{array}$ & $\begin{array}{l}\text { Genetic } \\
\text { layer }\end{array}$ & $\begin{array}{l}\text { Depth, in } \\
\text { cm }\end{array}$ & $\begin{array}{l}\text { Volume } \\
\text { mass, } \mathrm{g} / \mathrm{cm}\end{array}$ & $\begin{array}{l}\text { Specific } \\
\text { weight, } \\
q / \mathrm{cm}^{3}\end{array}$ & $\begin{array}{l}\text { Porosity, } \\
\text { in \% }\end{array}$ \\
\hline \multirow[t]{5}{*}{1} & \multirow[t]{5}{*}{ No erosion } & $A_{1}$ & $0-13$ & 1,20 & 2,67 & 55,06 \\
\hline & & $A_{2}$ & $13-31$ & 1,23 & 2,69 & 54,28 \\
\hline & & B & $31-50$ & 1,28 & 2,71 & 52,77 \\
\hline & & $B C$ & $50-72$ & 1,28 & 2,71 & 52,77 \\
\hline & & $C$ & $72-95$ & 1,33 & 2,69 & 49,44 \\
\hline \multirow[t]{3}{*}{2} & \multirow{3}{*}{$\begin{array}{l}\text { Medium } \\
\text { degree of } \\
\text { erosion }\end{array}$} & $A_{2}$ & $0-10$ & 1,24 & 2,68 & 53,74 \\
\hline & & 5 & $10-29$ & 1,29 & 2,72 & 52,57 \\
\hline & & $B C$ & $29-55$ & 1,34 & 2,70 & 50,37 \\
\hline
\end{tabular}

As a result of studies conducted in mountain gray-brown soils in Shamakhi region, erosion has weakened its fertility and led to its agrichemical properties, physical properties, and mechanical composition considerably.

The change in food in these lands, which are intensively used in agriculture, makes it clearer in the moderately eroded soils compared to non-eroded soils.

In the Gobustan region, which is $600-800 \mathrm{~m}$ above sea level, we find that the water-physical properties of these weakly and moderately degraded gray-brown soils are analyzed in genetically engineered samples. $[2,4,5]$

As can be seen from the table, the porosity at the top layer of the weakly wounded profile is $-52 \%$, whereas the overall porosity at the top layer of the moderately wetted profile was $50 \%$.

The special output was $2.53-2.97 \mathrm{q} / \mathrm{cm} 3$ on the upper floors. The thickness of the sliced sections is determined as follows (see Table 3)

It was found that $9.8 \%$ of the mildly washed (cut 1 ) soil moisture content was $9.8 \%$, moderately washed (cut 2) and $9.30 \%$ in the upper A-layer. In the next layer, the natural moisture has increased.

The hydroscopic moisture content was 3.04\% B and C 4.37 and $4.54 \%$ in the alluvial layer of the deteriorated soil. Humuscopic moisture in the soil profile subject to moderate erosion has been as follows. The upper layer was $3.02 \%$, and B C was 4.68 and 4.93 .

\section{Table 3}

\section{Fertility Indicators in Erozied Mountain-Brown Degraded Soils of Gobustan Region}




\begin{tabular}{|c|c|c|c|c|c|c|c|c|c|c|}
\hline \multirow{2}{*}{$\begin{array}{l}\text { Curvature } \\
\text { of the cut } \\
\text { or } \\
\text { fragility }\end{array}$} & \multirow{2}{*}{$\begin{array}{l}\text { Numbe } \\
r \quad \text { of } \\
\text { sliced } \\
\text { cuts }\end{array}$} & \multirow{2}{*}{$\begin{array}{l}\text { Gene } \\
\text { tic } \\
\text { layer }\end{array}$} & \multirow{2}{*}{$\begin{array}{l}\text { Depth, } \\
\text { sm }\end{array}$} & \multirow{2}{*}{$\begin{array}{l}\text { Humus } \\
\text { with }\end{array}$} & \multirow{2}{*}{$\begin{array}{l}\text { Total } \\
\text { nitrog } \\
\text { en } \\
\text { \%- } \\
\text { with }\end{array}$} & \multicolumn{5}{|c|}{ Absorbed grounds 100 land. mq / equ } \\
\hline & & & & & & $\mathrm{Ca}$ & Mэ & Total & $\begin{array}{l}\mathrm{Ca} \\
\%- \\
\text { with }\end{array}$ & $\begin{array}{l}\text { Mэ \%- } \\
\text { with }\end{array}$ \\
\hline \multirow{3}{*}{$\begin{array}{l}\text { North- } \\
\text { East } \\
\text { inclinatio } \\
n\end{array}$} & \multirow{4}{*}{\begin{tabular}{|l}
1 \\
Poorly \\
washed
\end{tabular}} & $A_{0}$ & $0-9$ & \multicolumn{7}{|c|}{ grass floor } \\
\hline & & A & $9-22$ & 4,8 & 0,308 & 30,0 & 4,0 & 34,0 & 88,0 & 12,0 \\
\hline & & 5 & $22-34$ & 4,0 & 0,224 & 25,5 & 5,0 & 30,5 & 84,0 & 16,0 \\
\hline $10^{0}$ & & C & $34-47$ & 1,4 & 0,084 & 17,5 & 3,0 & 20,5 & 85,0 & 15,0 \\
\hline $\begin{array}{l}\text { North- } \\
\text { East } \\
\text { inclinatio } \\
\mathrm{n} \\
12^{0}\end{array}$ & $\begin{array}{l}2 \\
\text { Middle } \\
\text { washed }\end{array}$ & A & $0-15$ & 4,0 & 0,252 & 29,0 & 4,5 & 33,5 & 86,0 & 14,0 \\
\hline
\end{tabular}

The erosion process on the southern slope of the Greater Caucasus, including the Gobustan, Shamakhi, Ismayilli and Aghsu regions, has widespread and has sharply deteriorated soil fertility. Here, the development of the erosion process, covering large areas, caused the complexity of the relief, the sharp change and the abundance of anthropogenic factors. The study also found that, in the erosioned soils, the amount of nutrients in the slopes was considerably reduced. Therefore, the normal development of agricultural crops cultivated in those lands is disrupted, resulting in low-quality products. Various agro-technical measures have been effectively utilized to bring such lands into good condition and to improve their lost fertility.

As a visual manifestation of this, it is possible to satisfy the biometric measurements and phenological observations on the plant with the experimental variant, as a result of the prediction of the research we have undertaken under the sowing plant in the Shamakhi region of the region. $[3,4]$

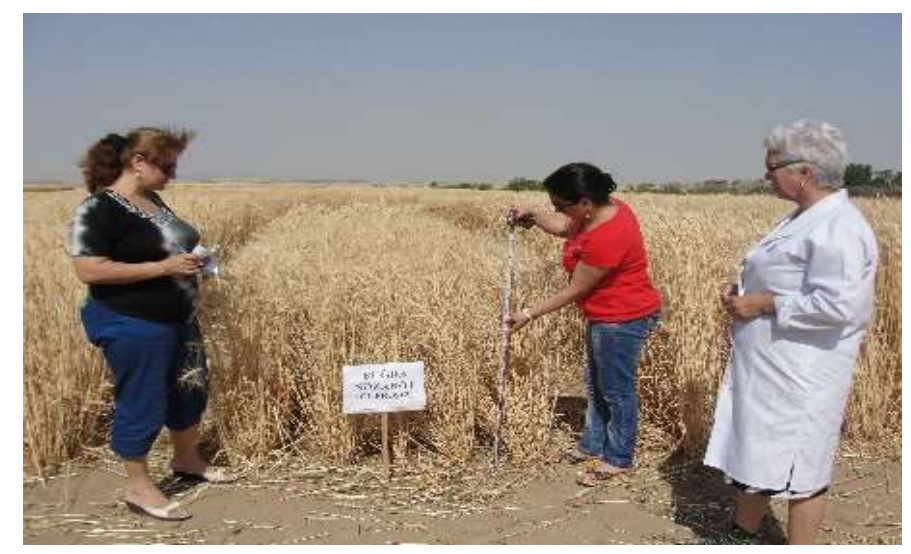

Note: Piping phase 06.07. 2019

Fiq.1 The phenological observation fragment in the field of practice 
Phenology observations on biological plants and biometric measurements

\begin{tabular}{|l|l|l|l|}
\hline Practice scheme & 1 st repetition & 2nd recurrence & 3rd repetition \\
\hline No fertile & 27 & 28 & 33 \\
\hline $\mathrm{N}_{30} \mathrm{P}_{30} \mathrm{~K}_{30}$ & 35 & 49 & 47 \\
\hline $\mathrm{N}_{45} \mathrm{P}_{60} \mathrm{~K}_{60}$ & 48 & 55 & 49 \\
\hline $\mathrm{N}_{60} \mathrm{P}_{60} \mathrm{~K}_{60}$ & & 57 & 54 \\
\hline $\mathrm{N}_{60} \mathrm{P}_{90} \mathrm{~K}_{60}$ & 49 & 50 & 69 \\
& 55 & & \\
\hline
\end{tabular}

Note The height of the plant (in cm); Piping phase 26.04. 2019

Growing of leguminous herbs in these lands for 2-3 years in improvement and enhancement of fertility of degraded soils is considered as one of the effective agro-technical measures.

The perennial herbs, primarily in the soil and clover, increase soil fertility by maintaining a large amount of organic matter while enriching soil with nitrogen $[2,7,8]$. As is known, plants are easier to absorb ammonia and nitrates than nitrogen.

These forms of nitrogen are more volatile. As the ammonia nitrogen is absorbed by the soil, it is hardly washed out by surface water flow and its loss is accompanied by soil.

Because nitrate nitrogen is not absorbed by the soil, it is easier to wash with surface water. Hence, ammonia and nitrates, which are soluble in water, are more environmentally friendly and are washed out of the soil by ordinary surface water. Therefore, in the eroded soils, plants suffer from nitrogen deficiency and develop very poorly [5].

The cultivation of perennial herbs in the degraded soils and providing them with mineral fertilizers is crucial. Since the early stages of perennial herbs have been reducing their underground and surface organisms intensively from the mineral fertilizers, using intravenous nutrients $[3,9,11]$

\section{Research Movements}

1. It should be recognized that during traditional soil cultivation, on average, over the years of research, the collection of winter wheat without fertilizing amounted to $32.8 \mathrm{c} /$ ha (Fig. 2).

2. In the version of manure $10 \mathrm{t} / \mathrm{ha}+\mathrm{N} 45 \mathrm{P} 60 \mathrm{~K} 60$, the grain yield is $40.1 \mathrm{c} / \mathrm{ha}$, the increase is $7.3 \mathrm{c} / \mathrm{ha}$ or $22.3 \%$.

3. The largest grain yield was obtained in the version of manure $10 \mathrm{t} / \mathrm{ha}+\mathrm{N} 60 \mathrm{P} 90 \mathrm{~K} 6057.1 \mathrm{c} / \mathrm{ha}$, an increase of $24.3 \mathrm{c} /$ ha or $74.1 \%$.

4. With a further increase in the doses of mineral fertilizers against the background of manure (N60P60K60), grain harvest increased slightly $-50.0 \mathrm{c} /$ ha, the increase was $17.2 \mathrm{c} /$ ha $(52.4 \%)$ of grain. 
5. Mathematical processing of the obtained data showed their reliability: $P=1.38-2.47 \% ; E=0.58-1.16 \mathrm{c} /$ ha

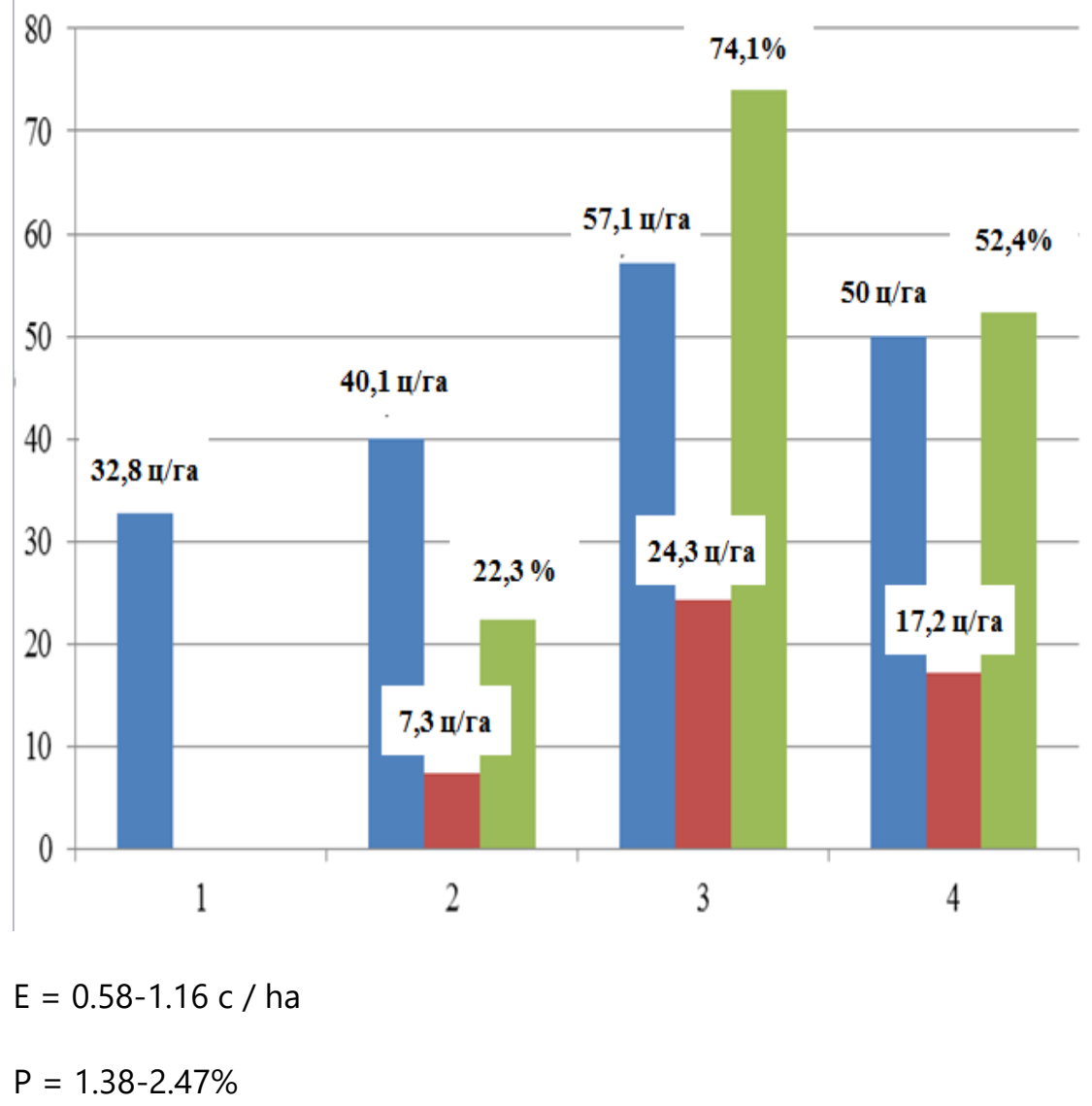

Fig.2. The influence of traditional processing and fertilizer rates on the yield of winter wheat (for 3 years)

With minimal soil treatment, on average, for the years of research, the collection of winter wheat grain in an unsophisticated version amounted to $30.6 \mathrm{c} /$ ha

\section{Results}

As a result, a lot of organic matter is accumulated in eroded soils, and the activity of microorganisms rises.Organic remnants of microorganisms significantly improve soil fertility and make them useful by increasing the amount of volatile food in the soil.

From the observations on the dynamics of the conservative forms of food in the degraded brown soils in the erosion, it is clear that the amount of poisonous nutrients was high in the early stages of fur and chimpanzee and gradually towards the end of the vegetation, during the harvesting period.

\section{CONCLUSION}

Thus, on the basis of the studies carried out, it can be concluded that in order to obtain a high and qualitative harvest of winter wheat grain and restore fertility of soils on gray-brown, long-irrigated soils to this zone, it is recommended that traditional farms (loosening 20-22 cm) and minimal tillage, also the use of fertilizers annually in the norm of manure is $10 \mathrm{t} / \mathrm{ha}+\mathrm{N} 60 \mathrm{P} 90 \mathrm{~K} 60 \mathrm{~kg} / \mathrm{ha}$. As a result, both cultivation of soil treatments and the rate of fertilizers are recommended; in addition, after 3 years, the minimum treatment should be replaced by a traditional one. 


\section{USED LITERATURE}

1. Aliyev H.A. - The use of the classification of rational use (as in the Eastern Caucasus). The rationalization of the rational use of the Northern Caucasus and the northern slopes of the hydrology. Principal.1971. h 53-62.

2. Alekperov K. A., 1980. Soil-erosion map of and protection of land Moscow

3. Aliev B.H. The problem of desertification in Azerbaijan and ways to solve it, "Ziya-Nurlan" publishinghouse Baku-2005

4. Aliev Z.H. Regional Geographic Problems of the Republic of Azerbaijan. (On Guba-Khachmaz economic region) Baku, 2006, $156 \mathrm{p}$.

5. Budagov B.A. Natural landscapes of Azerbaijan SSR and their protection. Baku, 1974, 156 p.

6. Budagov B.A. The natural landscapes of Soviet Azerbaijan. Baku,1988,230 p.

7. Budagov B.A. Natural phenomena of Azerbaijan. Baku, 1990, 208 p.

8. KA Alekberov. Protection of soil from erosion "Azernəşr," Baku, 1967.72 p.

9. H.G. - The effect of complex mineral fertilizers on the longitudinal and development of autumn wheat in eroded mountainous grassland. News of agricultural science № 5,1987.s. 97-100.

10. M.E. Salaev - Diagnosis and classification of Azerbaijan. Searching for "Elm" Baku, 1991. c. 162-170.

11. B.Sh.Shukuri - Physiological and biochemical bases of application of mineral fertilizers under wheat in the southeastern part of the Greater Caucasus, Baku, 2003. 